\title{
CAN A CHOICE-OF-COURT AGREEMENT INCLUDED IN A MARRIAGE CONTRACT MEET THE REQUIREMENTS OF BOTH EU SUCCESSION AND MATRIMONIAL PROPERTY REGULATIONS?
}

\author{
Iryna Dikovska *
}

\begin{abstract}
Due to the fact that matrimonial property and inheritance issues are closely intertwined, in some situations the determination of rules which should be applicable to particular relationships seems problematic. This fully applies to marriage contracts which cover both types of issues. The presence of a cross-border element in such contracts raises the question of the delineation of the legal regimes of the Matrimonial Property Regulation and the Succession Regulation applicable to matrimonial property and succession issues respectively. This paper analyses the rules which should be applicable to choice-ofcourt agreements for matters arising out of marriage contracts which cover both matrimonial property and inheritance issues and include a cross-border element. For this reason, the paper reveals the interaction between the regimes of the Matrimonial Property Regulation and the Succession Regulation, and the requirements of choice-ofcourt agreements under both regulations. Some of the requirements of these regulations of choice-of-court agreements coincide (eg formal requirements), while others differ. The main differences include: the precondition for the conclusion of a choice-of-court agreement under the Succession Regulation, which is not required under the Matrimonial Property Regulation; the courts which may be chosen; and the circle of matters which can be resolved by the courts on the basis of the choice-of-court agreement. It is concluded that a choice-of-court agreement, included in the marriage contract, can meet the requirements of both the Succession Regulation and the Matrimonial Property Regulation if: the dispositions upon the death of a spouse, included in the marriage contract, are an 'agreement as to succession' in the meaning of Article 3(1)(b) of the Succession Regulation; the marriage contract includes a choice-of-law agreement in favour of the law of the Member State whose nationality a deceased spouse possessed when the choice-of-law agreement was concluded; this choice of law agreement covers the succession of the deceased spouse 'as a whole';
\end{abstract}

\footnotetext{
" Professor, Civil Law Department, Faculty of Law, Taras Shevchenko National University of Kyiv, Ukraine, orcid.org/0000-0002-0728-3934. Contact: irinadikovska@hotmail.com. The author is grateful to the Max Planck Institute for Comparative and International Private Law for hospitality and financial support, which allowed her to compose this paper as a visiting researcher of the Institute. DOI: 10.3935/cyelp.15.2019.348.
} 
the choice-of-court agreement grants jurisdiction to the courts of the Member State whose nationality a deceased spouse possessed at the time of the conclusion of the choice-of-law agreement; it provides the jurisdiction of 'the courts' of a Member State (not 'a court').

Keywords: choice-of-court agreement, EU Succession Regulation, EU Matrimonial Property Regulation, synchronisation between law and forum, agreement as to succession, matrimonial property agreement, marriage contract.

\section{Introduction}

The national law of some Member States admits marriage contracts which provide a matrimonial property regime other than that which is stipulated by the law. In particular, they may determine which property is the individual property of each of the spouses, the share of each of them in the matrimonial property, the order of its management and disposition, and other issues. ${ }^{1}$ In some legal systems, among other things, the contracts can stipulate the legal consequences of the death of one of the spouse, eg the donation of future property upon the death of one them to the other, the powers of the surviving spouse that change the inheritance rights of the surviving spouse of sharing the property of the deceased among children. ${ }^{2}$ Thus, some marriage contracts can combine both matrimonial property and inheritance issues. The presence of a cross-border element in such contracts raises the question of the delineation of legal regimes of the Matrimonial Property Regulation ${ }^{3}$ and the Succession Regulation ${ }^{4}$ applicable to matrimonial property and succession issues respectively.

This paper focuses on the requirements of choice-of-court agreements under both Regulations and addresses the question of whether a choice-of-court agreement included in the marriage contract, which combines both matrimonial property and inheritance issues, meets the requirements of both the Succession Regulation and the Matrimonial

\footnotetext{
1 Petar Šarčević and Ivana Kunda, 'Property Rights in the Family' in W Pintens, R Blanpain and F Hendrickx (eds), International Encyclopaedia for Family and Succession Law Croatia (2013) 188-189.

2 Gabriel Garcia Cantero, 'Matrimonial Property Law' (2013) International Encyclopaedia for Family and Succession Law Spain 237.

3 Council Regulation (EU) 2016/1103 of June 2016 implementing enhanced cooperation in the area of jurisdiction, applicable law and the recognition and enforcement of decisions in matters of matrimonial property regimes [2016] OJ L183/1.

4 Regulation (EU) No 650/2012 of the European Parliament and of the Council of 4 July 2012 on jurisdiction, applicable law, recognition and enforcement of decisions and acceptance and enforcement of authentic instruments in matters of succession and on the creation of a European Certificate of Succession [2012] OJ L201/107.
} 
Property Regulation. Since the answer to this question depends on general rules concerning coordination between these instruments, we first consider the issue of their interaction.

\section{Interaction between matrimonial property and succession regulations.}

The Matrimonial Property Regulation and the Succession Regulation stipulate mechanisms for avoiding an overlap between their provisions. However, with regard to jurisdiction, the Succession Regulation does not contain any rules which directly solve the conflicts of jurisdictions if the succession case includes matrimonial property matters which have arisen in connection with it. Therefore, to determine the path of this instrument in the matter of the coordination of jurisdictions regarding such cases, one should analyse the circle of issues covered by the Succession Regulation and the exclusions from them.

According to Article 1(1) of the Succession Regulation, it applies to succession to the estates of deceased persons. The rules which determine jurisdiction also emphasise that they concern 'succession', ${ }^{5}$ which is determined as 'succession to the estate of a deceased person and covers all forms of transfer of assets, rights and obligations by reason of death, whether by way of a voluntary transfer under a disposition of property upon death or a transfer through intestate succession. ${ }^{6}$ To clarify this definition, commentators usually refer to Article 23(2) of the Succession Regulation which stipulates the scope of the applicable law, but its provisions are used for the purpose of determining international jurisdiction as well. ${ }^{7}$ In this connection, it should be mentioned that under Article 23(2)(b) of the Succession Regulation, the law applicable to succession includes 'the determination of the beneficiaries, of their respective shares and of the obligations which may be imposed on them by the deceased, and the determination of other succession rights, including the succession rights of the surviving spouse or partner'. Therefore, the international jurisdiction to rule on the issues regarding the succession rights of the surviving spouse is also governed by the Succession Regulation.

It is important that the term 'inheritance rights' used in Article 23(2)(b) of the Succession Regulation covers the rights of the surviv-

\footnotetext{
5 In particular, Articles 4 and 10 of the Succession Regulation grant the 'jurisdiction to rule on the succession as a whole'; Article 5 mentions 'exclusive jurisdiction to rule on any succession matter'; Article 11 sets down the jurisdiction 'rule on the succession', etc.

6 Succession Regulation, Art 3(1)(a).

7 George Nikolaidis, 'Article 1: Scope' in Haris Pamboukis (ed), EU Succession Regulation No 650/2012: A Commentary (Beck/Hart 2017) 24.
} 
ing spouse to the estate arising out of testamentary disposition upon death or, in the case of intestate succession, personal closeness to the deceased ${ }^{8}$ On the other hand, the rights arising directly from a marriage or its dissolution, ${ }^{9}$ aimed at the division of property for compensation of the contribution to the marriage of one of the spouses in relation to the contribution of the other spouse ${ }^{10}$ or, in other words, at balancing the economic conditions during the marriage, ${ }^{11}$ are characterised as part of the matrimonial property relationships. ${ }^{12}$ Consequently, they are not covered by the Succession Regulation since the issues relating to matrimonial property regimes are excluded from its scope. ${ }^{13}$ At the same time, 'the authorities dealing with a given succession ... should ... depending on the situation, take into account the winding-up of the matrimonial property regime ... of the deceased when determining the estate of the deceased and the respective shares of the beneficiaries'. ${ }^{14}$ In this case, the matrimonial property regime issue is considered as preliminary to the main issue of succession. ${ }^{15}$

At the same time, distinguishing between matrimonial property and succession issues has been called 'a classical problem of characterization'. ${ }^{16}$ However, to protect the surviving spouse, national laws use dif-

\footnotetext{
8 Jan Peter Schmidt, 'Artikel 1 EuErb VO' in Anatol Dutta, Johannes Weber (eds), Internationales Erbrecht: EuErbVO, Erbrechtliche Staatsverträge, EGBGB, IntErbRVG, IntErbStR, IntSchenkungsR (CH Beck 2016) 72; Angelo Davi, 'Scope and Definitions' in Alfonso-Luis Calvo Caravaca, Angelo Davì and Heinz-Peter Mansel (eds), The EU Succession Regulation Commentary (CUP 2016) 88.

9 Schmidt (n 8) 71.

$10 \quad$ Davi (n 8) 89.

11 Schmidt (n 8) 72.

12 Schmidt (n 8) 71- 72; Davi (n 8) 88-89.

13 Succession Regulation, Art 1(2)(d). However, the term 'matrimonial property regime' is not defined in the Succession Regulation. Article 3(1)(a) of the Matrimonial Property Regulation determines it as 'a set of rules concerning the property relationships between the spouses and in their relations with third parties, as a result of marriage or its dissolution'. It is considered that all the issues included in the scope of law applicable to the matrimonial property regime according to Article 27 of the Matrimonial Property Regulation are covered by the 'matrimonial property regime'. In particular, they include: (a) the classification of property of either or both spouses into different categories during and after marriage; (b) the transfer of property from one category to the other; (c) the responsibility of one spouse for the liabilities and debts of the other spouse; (d) the powers, rights and obligations of either or both spouses with regard to property; (e) the dissolution of the matrimonial property regime and the partition, distribution or liquidation of the property; (f) the effects of the matrimonial property regime on a legal relationship between a spouse and third parties; (g) the material validity of a matrimonial property agreement. Barbara Reinhartz, 'Article 3: Definitions' in Ulf Bergquist and others (eds), The EU Regulations on Matrimonial and Patrimonial Property (OUP 2019) 40.

14 ibid.

15 Nikolaidis (n 7) 32.

16 Davi (n 8) 87.
} 
ferent mechanisms of matrimonial property or succession law, ${ }^{17}$ and the legal nature of some of them has been disputable. For example, under $\S 1371(1)$ of the German Civil Code (hereinafter: BGB), in the case of the termination of the matrimonial property regime by the death of one of the spouses, the equalisation of the accrued gains is effected by the share of the inheritance on intestacy of the surviving spouse, which is increased by one quarter of the inheritance.

Since this rule stipulates the consequences of the termination of the matrimonial property regime by reference to the concept used in succession law, its characterisation was disputable in German law for years. ${ }^{18}$

At the same time, the characterisation of $\S 1371(1)$ BGB for the purposes of the Succession Regulation cannot be based on German doctrine; rather, it should be grounded on European conflict of law rules, binding for all Member States. ${ }^{19}$ This is why, in a recent case, the CJEU, referring to the Opinion of the Advocate General, determined the legal nature of $\S 1371(1) \mathrm{BGB}$ by stating that:

Paragraph 1371(1) of the BGB concerns not the division of assets between spouses but the issue of the rights of the surviving spouse in relation to assets already counted as part of the estate. Accordingly, that provision does not appear to have as its main purpose the allocation of assets or liquidation of the matrimonial property regime, but rather determination of the size of the share of the estate to be allocated to the surviving spouse as against the other heirs. Such a provision therefore principally concerns succession to the estate of the deceased spouse and not the matrimonial property regime. ${ }^{20}$

\footnotetext{
17 Jürgen Basedow et al, 'Comments on the European Commission's Proposal for a Regulation of the European Parliament and of the Council on jurisdiction, applicable law, recognition and enforcement of decisions and authentic instruments in matters of succession and the creation of a European Certificate of Succession' (2010) 74(3) Rabels Zeitschrift für ausländisches und internationales Privatrecht 522, 527-528.

18 Jan Peter Schmidt mentions three possible types of characterisation of § 1371(1) BGB in German doctrine. According to the first point of view, one should employ property law characterisation in this case; another suggestion was to use succession law characterisation; the third approach offered double characterisation. The possibility of the application of § 1371(1) BGB to a particular case depends on the type of characterisation employed. For example, the matrimonial property law characterisation of § 1371(1) BGB means that this Article would be applicable if German law governs matrimonial property issues. Succession law characterisation leads to the application of this rule if German law governs inheritance issues. Double characterisation stands for its application if German law governs both matrimonial property and inheritance issues. The property law characterisation of $\S 1371(1)$ BGB is considered as convincingly justified taking into consideration its aim: to balance the gains accrued during the marriage. In this case, inheritance is considered only as the instrument used for achievement this goal. See Schmidt (n 8) 72-73.

19 ibid.

20 Case C-558/16 Mahnkopf ECLI:EU:C:2018:138, para 40. In this case, the request for a preliminary ruling concerned the interpretation of some articles of the Succession Regulation.
} 
Therefore, the CJEU used the succession law characterisation of $\S$ 1371(1) BGB, even though it was expected that for the purposes of the Succession Regulation, the matrimonial property law characterisation of $\S 1371(1)$ BGB would be employed because of the functional considerations of this provision. ${ }^{21}$

Thus, it can be concluded that for the purposes of the Succession Regulation the characterisation of the provision as one of matrimonial property or succession according to the CJEU depends on whether it determines the fate of the estate after the death of one of the spouses. If it does, it is a succession law provision. If it governs only the allocation of the assets or liquidation of the matrimonial property regime and does not concern the fate of the estate after the death of one of the spouses, it sets down the matrimonial property regime. It can be expected that this path will be used for the characterisation of other national law rules in the case of doubts as to property or of a succession law nature for the purposes of the Succession Regulation. ${ }^{22}$

${ }_{21}$ Davi (n 8) 90; Schmidt (n 8) 72.

22 Among them, for example, are the rules of $\S 1371(2-4)$ BGB. Paragraph 1371(2) BGB stipulates two rules. Under the first, the surviving spouse, who has not become an heir or legatee, is entitled to demand equalisation of the accrued gains under the provisions of $\S \S 1373$ to 1383 and $\S 1390$ BGB. The second rule lays down that the compulsory portion of the surviving spouse or of another person entitled to a compulsory portion is determined in this case with reference to the share of the inheritance on the intestacy of the spouse before it is increased. The first rule is characterised as matrimonial property law rules, because, despite the fact that it mentions terms of inheritance law, it is aimed at the equalisation of gains. Schmidt (n 8) 73. The second rule of this paragraph is characterised as an inheritance law provision since it governs compulsory portion. Schmidt (n 8) 73. The same applies to \$1371(3) BGB. Schmidt (n 8) 73. (This paragraph entitles the surviving spouse, who disclaims the inheritance, to demand the compulsory portion, in addition to the equalisation of the accrued gains, even if this surviving spouse has no entitlement to this under the provisions of the law of succession. This rule does not apply if the surviving spouse has waived his or her right of intestate succession or the right to a compulsory portion by a contract with the spouse). Paragraph 1371(4) BGB stipulates the duty of the surviving spouse to grant the descendants of the deceased spouse, who are entitled to inherit, and who are not descended from the marriage ended by the death of this spouse, to grant these descendants, if and to the extent that they need these, the means for a reasonable education from the quarter additionally granted under § 1371(1) BGB. Since the claim of the descendants of the deceased spouse, stipulated by $\S 1371(4)$ BGB, will rise from a property law quarter provided by $\S$ 1371(1) BGB, the rule of $\S 1371(4)$ BGB is characterised as a property law provision because it needs synchronisation with the rule of § 1371(1) BGB. Schmidt (n 8) 73.

Another example is $\S 1931(4)$ BGB, which stipulates the equal shares of the surviving spouse and children of the deceased in the case of the separation of property at the time of the devolution of the inheritance and if one or two children of the deceased are entitled as heirs on intestacy together with the surviving spouse. Therefore, this paragraph makes the inheritance of the surviving spouse dependent on the matrimonial property regime and is usually qualified as a succession law provision. Commentators emphasise the decisive difference between the rules of § 1931(4) and § 1371(1) BGB, since the first of these rules is an original provision of the law of succession; the second is a rule of matrimonial property law, which uses the concept of succession law as an instrument. Schmidt (n 8) 73-74.

One more illustration is the national rules which grant the surviving spouse the right to 
The exclusion of matrimonial property issues from the scope of the Succession Regulation also concerns marriage settlements 'to the extent that such settlements do not deal with succession matters'. ${ }^{23}$ In some legal orders, marriage settlements can determine the fate of the objects of matrimonial property in the case of the death of one of the spouses. The example is 'avantages matrimoniaux', known in French law, determined as 'advantages that one spouse may infer from the clauses of a contractual community regime. ${ }^{24}$ In practice, 'avantages matrimoniaux' arise out of the agreement between spouses, under which the surviving spouse receives all or some objects of the common matrimonial property in the case of the death of the other spouse. ${ }^{25}$ If such an agreement possesses the features of the agreement as to succession in the sense of Article 3(1)(b) of the Succession Regulation, ${ }^{26}$ it falls within its scope. In other words, if the purpose of the agreement between the spouses is to make a donation in the case of the death of one of them, from the functional point of view, it has the character of an agreement as to succession in the sense of the Succession Regulation. ${ }^{27}$ Consequently, it is covered by the Succession Regulation.

vote regarding his or her inheritance and which are usually characterised as succession law rules. Jan Peter Schmidt, 'Artikel 1 EuErb VO' 74. They include, for example, the rule of Article 442-5 of the Civil Code of Catalonia, which entitles the surviving spouse to 'opt to exchange universal usufruct for the attribution of an aliquot fourth of the inheritance and, moreover, usufruct of the family or marital dwelling'. See Law 10/2008 of 10 July of the Fourth Book of the Civil Code of Catalonia, Regarding Succession, Tram. 200-00017/08, Parlament de Catalunya <https://www.parlament.cat/document/intrade/152464> accessed 9 August 2019. Another example is Article 757 of the French Civil Code, which guarantees the surviving spouse the right to choose to take the usufruct of the whole of the existing property or the ownership of the quarter if the deceased spouse left children, all of whom were born from both spouses, and the ownership of the quarter in the presence of one or several children who were not born from both spouses.

23 Succession Regulation, Recital 12.

24 Frédérique Ferrand, Bente Braat, Property Relationship between Spouses. National Report: France (Commission on European Family Law 2008) $5<$ http://ceflonline.net/wp-content/uploads/France-Property.pdf> accessed 9 August 2019.

25 Schmidt (n 8) 74.

26 Under Article 3(1)(b) of the Succession Regulation, agreement as to succession is 'an agreement, including an agreement resulting from mutual wills, which, with or without consideration, creates, modifies or terminates rights to the future estate or estates of one or more persons party to the agreement'. This definition allows determining the following characteristic features of the agreements as to succession provided by the Succession Regulation: they require bilateral expression of consent of their parties to be concluded (since they are 'agreements); they transfer the estate upon the death of a person; they concern the estate of a person party to the agreement. Juliana Rodriguez Rodrigo 'Article 25: Agreements as to Succession' in Calvo Caravaca, Davì and Mansel (n 8) 381; Frank Bauer, 'Artikel 25 EuErb VO' in Anatol Dutta, Johannes Weber (eds), Internationales Erbrecht: EuErbVO, Erbrechtliche Staatsverträge, EGBGB, IntErbRVG, IntErbStR, IntSchenkungsR $(\mathrm{CH}$ Beck 2016) 205; George Nikolaidis, 'Article 3: Definitions' in Pamboukis (n 7) 97; Christos Zoumpoulis, 'Article 25: Agreements as to Succession' in Pamboukis (n 7) 302.

27 Schmidt (n 8) 74. 
The issue of succession to the estate of a deceased spouse is excluded from the scope of the Matrimonial Property Regulation. ${ }^{28}$ At the same time, all the civil-law aspects of the liquidation of matrimonial property regime 'in particular as a result of ... the death of one of the spouses' are covered by the Matrimonial Property Regulation. ${ }^{29}$ That is why the demarcation between the Succession Regulation and the Matrimonial Property Regulation is considered questionable. ${ }^{30}$ Its Article 4 provides the coordination of jurisdictional rules of the Succession Regulation and the Matrimonial Property Regulation ${ }^{31}$ by granting jurisdiction in respect of matrimonial property regime matters connected with the succession case to a court of a Member State seized under the Succession Regulation. ${ }^{32}$ This approach of the Matrimonial Property Regulation is explained by its primary task 'to ensure ... that jurisdiction is given to the court that is seized of the main question'. ${ }^{33}$

The wording of Article 4 of the Matrimonial Property Regulation, which confirms the jurisdiction of a court of a Member State, where it is seized in matters of the succession of a spouse pursuant to Regulation (EU) No 650/2012' raises a question: can the jurisdiction to rule on the succession of a spouse be governed by the Matrimonial Property Regulation if no court was seized pursuant to the Succession Regulation, and if there is a choice-of-court agreement included in the marriage contract which covers both matrimonial property and succession issues, and which provides that all issues arising out of this contract shall be settled by the courts of a Member State, determined under one of the rules of Article 7 of the Matrimonial Property Regulation?

In our opinion, in such a situation the jurisdiction to rule on succession cannot be determined under the rules of the Matrimonial Property Regulation. This is explained by the fact that succession of the estate of a deceased spouse is excluded from the Matrimonial Property Regulation. Secondly, the provisions of the Matrimonial Property Regulation were

\footnotetext{
28 Matrimonial Property Regulation, Art 1(2)(d), Recital 22.

29 Matrimonial Property Regulation, Recital 18.

30 Marlene Brosch, Rechtswahl und Gerichtsstandsvereinbarung im internationalrn Familien- und Erbrecht der EU (Mohr Siebeck, Tuebingen 2019) 88.

31 Cristina Grieco, 'The Role of Party Autonomy Under the Regulations on Matrimonial Property Regimes and Property Consequences of Registered Partnerships. Some Remarks on the Coordination Between the Legal Regime Establishes by the New Regulations and Other Relevant Instruments of European Private International Law' (2018) 10(2) Cuadernos de Derecho Transnacional 457, 462-463.

32 See also the Matrimonial Property Regulation, Recitals 22, 32, 33.

33 Richard Frimston, 'Article 4: Jurisdiction in the Event of Death of One of the Spouses' in Ulf Bergquist and others (n 13) 50.
} 
created to apply to the matrimonial property regime and are not suitable to be applied to succession. In the context of choice-of-court agreements, this instrument does not contain provisions which provide the consequences of the conclusion of a choice-of-court agreement by not all the parties concerned, as the Succession Regulation does. Thirdly, if the law applicable to the marriage contract is other than the law of the Member State whose nationality the deceased spouse possessed at the time of making the choice of law, the application of the jurisdictional rules of the Matrimonial Property Regulation will not allow one of the main purposes of governing succession relationships in EU law to be achieved - to ensure synchronisation between law and forum. ${ }^{34}$

It should be mentioned that the Matrimonial Property Regulation is applicable:

in the Member States which participate in enhanced cooperation in the area of jurisdiction, applicable law and the recognition and enforcement of decisions on the property regimes of international couples, covering both matters of matrimonial property regimes and the property consequences of registered partnerships, as authorized by Decision (EU) $2016 / 954 .^{35}$

These include 18 EU Member States. ${ }^{36}$ If a court of an EU Member State which does not apply the Matrimonial Property Regulation is

\footnotetext{
${ }_{34}$ The possibility to choose the courts of a Member State under Article 7(1) of the Matrimonial Property Regulation depends on the law applicable to the matrimonial property regime. A comparison of Articles 22, 26 of the Matrimonial Property Regulation and Articles 21, 22 of the Succession Regulation shows that the range of options for the choice of applicable law for the parties and for the court in the absence of the parties' choice is broader than under the Succession Regulation. Unlike the Matrimonial Property Regulation, the Succession Regulation allows the following to be applied: the law of the state of the habitual residence of the deceased (Article 21(1)); the law of nationality of the deceased (if he or she has chosen it as an applicable law) (Article 22 (1)); the law of the State with which the deceased was more closely connected at the time of death (Article 21(2)). Besides, under Article 7(1) of the Matrimonial Property Regulation the parties may choose the jurisdiction of the courts of the Member State where the marriage was concluded. So, if, for example, the chosen court is the court of the State where the marriage was concluded, it has no possibility to apply its own law to succession since the Succession Regulation does not provide the possibility to apply to succession the law of the State where the marriage was concluded. Synchronisation between law and forum in this situation is possible only if the State where the marriage was concluded coincides with the State of the habitual residence of the deceased or with the State whose nationality he or she possessed (if there was a choice of law) or if this law is the law of the State with which the deceased was more closely connected at the time of death.

35 Matrimonial Property Regulation, Article 70(2).

36 Namely, the Kingdom of Belgium, the Republic of Bulgaria, the Czech Republic, the Federal Republic of Germany, the Hellenic Republic, the Kingdom of Spain, the French Republic, the Republic of Croatia, the Italian Republic, the Republic of Cyprus, the Grand Duchy of Luxembourg, Malta, the Kingdom of the Netherlands, the Republic of Austria, the Portuguese Republic, the Republic of Slovenia, the Republic of Finland and the Kingdom of Sweden. Council Decision (EU) 2016/954 of 9 June 2016 authorizing enhanced cooperation in
} 
seized in a succession case under the Succession Regulation, Article 4 of the Matrimonial Property Regulation is not applied. In such circumstances, the jurisdiction on a matter of the spouses' matrimonial property regime is determined under Article 6 of the Matrimonial Property Regulation. ${ }^{37}$

The rules of jurisdictions to rule on a matter of the spouses' matrimonial property regime in cases that are not connected with a succession case, of which the court of the Member State is seized, are determined by the Matrimonial Property Regulation. ${ }^{38}$ Whether a particular matter is connected with a succession case should be decided by the court seized in a succession case. ${ }^{39}$ The term 'connected with that succession case', used in Article 4 of the Matrimonial Property Regulation, is understood as one which has a looser meaning in comparison with the term 'in matters related to' employed in other EU law instruments (Articles 7, 10, 17 of the Brussels I bis Regulation)..$^{40}$

The rules of this Regulation apply to the 'matrimonial property agreement' which is understood as 'any agreement between spouses or future spouses by which they organize their matrimonial property regime. ${ }^{41}$ In turn, the matrimonial property regime is 'a set of rules concerning the property relationships between the spouses and in their relations with third parties, as a result of marriage or its dissolution. ${ }^{42}$ Therefore, the provisions of marriage contracts which regulate property relationships between the spouses (eg determine the share of each of the spouses in matrimonial property) and in their relations with third parties and which do not create, modify or terminate rights to the future estate or estates of one the spouses or both of them are considered as matrimonial property agreements within the meaning of the Matrimonial Property Regulation and fall within its scope.

Therefore, in general, succession issues are excluded from the scope of the Matrimonial Property Regulation, and matrimonial property issues are not covered by the Succession Regulation. However, matrimonial property issues can be considered by the court handling the succession case according to the Succession Regulation as a preliminary

the area of jurisdiction, applicable law and the recognition and enforcement of decisions on the property regimes of international couples, covering both matters of matrimonial property regimes and the property consequences of registered partnerships [2016] OJ L159.

37 Frimston (n 33) 49.

38 Matrimonial Property Regulation, Art 6, Recital 35.

39 Frimston (n 33) 49.

40 ibid, 59.

41 Matrimonial Property Regulation, Art 3(1)(b).

42 Matrimonial Property Regulation, Art 3(1)(a). 
question, and consequently this court has jurisdiction regarding matrimonial property issues arising in this case. The provisions of marriage contracts which govern property relationships between the spouses and in their relations with third parties, as a result of marriage or its dissolution, should be classified as a matrimonial property agreement within the meaning of the Matrimonial Property Regulation. The provisions of marriage contracts which govern the creation, modification or termination rights to the future estate or estates of one the spouses or both of them should be classified as an agreement as to succession within the meaning of the Succession Regulation.

\section{Choice-of-court agreements under the Succession Regulation}

\subsection{The reasons for the inclusion of choice-of-court agreement provisions in the Succession Regulation}

The Succession Regulation has been called 'the most ambitious and comprehensive project concerning measures aimed at ensuring the compatibility of rules applicable in the Member States concerning conflict-of-law and jurisdiction'. ${ }^{43}$ This compatibility is achieved through a set of mechanisms, one of which consists of the possibility to conclude a choice-of-court agreement of a court or courts of the Member State whose law has been chosen as applicable to succession by the deceased. The choice-of-court agreement provided by the Succession Regulation can facilitate the inheritance proceedings for the heirs and other parties concerned by the succession. This is particularly the case if the state of habitual residence of the deceased at the time of death and the state of his or her nationality (which is also the state of residence and nationality of the heirs and other parties concerned) do not coincide. The absence of a choice-of-court agreement would lead to the determination of jurisdiction under Article 4 or Article 10 of the Succession Regulation, which in this situation means that the parties concerned should apply to the court of the state other than a court of the state of their residence and nationality. Thus, the choice-of-court agreement can render the inheritance proceedings more convenient for the parties concerned. Besides, it gives them other benefits than those given by any other choice-of-court agreement. $^{44}$

\footnotetext{
43 David Paulus, 'Succession and Company Law' in S Bariatti, I Viarengo, FC Villata (coordinators), Towards the Entry into Force of the Succession Regulation: Building Future Uniformity upon Past Divergencies (Università degli Studi di Milano 2016) 133.

44 Usually they include certainty, predictability to the parties, the possibility to lower costs, and some other benefits. See Zheng Sophia Tang, 'Conflict of Jurisdiction and Party Autonomy in Europe' (2012) 59(3) Netherlands International Law Review 321, 323.
} 
Moreover, the choice-of-court agreement provided by the Succession Regulation in some sense facilitates the application of the law for the court exercising jurisdiction in a particular inheritance case, because it leads to the application of the court's own law.

Despite the advantages of the choice-of-court agreement, neither the Proposal for the Succession Regulation ${ }^{45}$ nor the Draft Report on the Proposal for the Succession Regulation ${ }^{46}$ provided the possibility to conclude a choice-of-court agreement to allow for synchronisation between the applicable law and jurisdiction in the case where a deceased person has chosen an applicable law to the succession. As follows from the Comments to Article 5 of the Proposal for the Succession Regulation, the court of the state whose law was chosen by the deceased could be considered as more appropriate, although referral to it should not be automatic. This approach has been criticised. ${ }^{47}$ Indeed, under the Proposal for the Succession Regulation, the jurisdiction of the courts of the states of the chosen law depended not on the discretion of the parties concerned, but on the court's discretion based on the request of one of them. This conclusion follows from its Article 5(1), under which the court seized in accordance with Article 4 had the powers at the request of one of the parties to stay proceedings and invite the parties to seize the courts of a Member State whose law was chosen by the deceased to govern the succession 'if it considers that the courts of the Member State whose law has been chosen are better placed to rule on the succession'. Certainly, this could create some inconvenience to the other parties concerned who did not make a request. ${ }^{48}$

45 Commission, 'Proposal for a Regulation of the European Parliament and of the Council on jurisdiction, applicable law, recognition and enforcement of decisions and authentic instruments in matters of succession and the creation of a European Certificate of Succession' COM (2009) 0154 final.

46 European Parliament, 'Draft Report on the Proposal for a regulation of the European Parliament and of the Council on jurisdiction, applicable law, recognition and enforcement of decisions and authentic instruments in matters of succession and the creation of a European Certificate of Succession' COD (2009) 0157.

47 Eva Lein, 'Artikel 5 EuErb VO' in Anatol Dutta, Johannes Weber (eds), Internationales Erbrecht: EuErbVO, Erbrechtliche Staatsverträge, EGBGB, IntErbRVG, IntErbStR, IntSchenkungsR (CH Beck 2016) 114. However, the Draft Report on the Proposal, although it contained some amendments to Article 5, did not offer to include into the future Regulation provisions concerning choice-of-court agreements.

48 The possibility to make the determination of jurisdiction in the case of choice of law made by the deceased dependent on the discretion of the deceased or the court has been discussed in doctrine. In particular, it was proposed to amend Article 5 of the Succession Regulation in such a way as to allow the deceased to choose not only the applicable law of the Member State, but also a court or courts of that Member State to rule on succession matters. If the deceased has chosen the law of the Member State but has not chosen the jurisdiction, the courts of the Member State whose law was chosen obtain exclusive jurisdiction to rule on succession matters automatically. It is expected that such amendments 
The fact that Article 25 of the Brussels I bis Regulation, ${ }^{49}$ Article 4 of the Maintenance Regulation, ${ }^{50}$ and the national legislation of some Member States granted the right to conclude a choice-of-court agreement, ${ }^{51}$ and Article 87(2) of Switzerland's Federal Code on Private International Law provided a mechanism of synchronisation between law and forum of the state of citizenship of the deceased if the deceased had his or her last domicile abroad, ${ }^{52}$ also served as arguments to include in the Succession Regulation the provisions regarding the choice-of-court agreement. ${ }^{53}$

Thus, the main reason for the inclusion in the Succession Regulation of the rules admitting the choice-of-court agreements was the desire to achieve synchronisation between jurisdiction and applicable law for the facilitation of the succession process for the parties concerned and for the court. An additional reason for this inclusion was that the choice-of-court agreements were already known in other EU Regulations dealing with the cross-border jurisdiction and private international law rules of some countries.

would provide synchronisation between law and forum in all cases when the deceased has chosen the applicable law (the current version of Article 5 will not always lead to this result, since the parties concerned may not conclude a choice-of-court agreement) and would increase the predictability of the succession process. Besides, it would facilitate the process, since examination of whether all the parties of the proceedings were the parties to a choice-of-court agreement would be unnecessary. Brosch (n 30) 233-237. However, despite the benefits of these possible amendments, we support another point of view, according to which giving the deceased the right to choose the jurisdiction for the proceedings, in which he or she will not be involved, since they will take place after his or her death, will unjustly restrict the parties concerned in choosing the jurisdiction. Fabrizio Marongiu Buonaiuti, 'Article 5: Choice-of-Court Agreement' in Calvo Caravaca, Davì and Mansel (n 8) 151. This fully applies also to the automatic grant of jurisdiction to the courts of the Member State whose law was chosen, since the convenience of the parties is more important than the synchronisation between law and forum, which contributes to the convenience of the court.

49 Council Regulation (EC) 2201/2003 of 27 November 2003 concerning jurisdiction and the recognition and enforcement of judgments in matrimonial matters and the matters of parental responsibility, repealing Regulation (EC) 1347/2000 [2003] OJ L338/1.

50 Council Regulation (EC) 4/2009 of 18 December 2008 on jurisdiction, applicable law, recognition and enforcement of decisions and cooperation in matters relating to maintenance obligations [2009] OJ L7/1.

51 Among them are Germany, Austria, Belgium, Greece, and the Netherlands. See Deutsches Notarinstitut, Heinrich Dörner, Paul Lagarde, 'Étude de droit comparé sur les règles de conflits de juridictions et de conflits de lois relatives aux testaments et successions dans les Etats membres de l'Union Européenne. Rapport Final: Synthèse et Conclusions 18 septembre/8 novembre 2002'19 <http://ec.europa.eu/civiljustice/publications/docs/ testaments_successions_fr.pdf>_accessed 10 May 2019.

52 Bundesgesetz über das Internationale Privatrecht (IPRG) vom 18. Dezember 1987 (Stand am 1. Januar 2019) <www.admin.ch/opc/de/classified-compilation/19870312/index.html> accessed 10 May 2019.

53 Lein (n 47) 114-115. 


\subsection{Precondition for a choice-of-court agreement}

In comparison with court-of-choice agreements provided by other EU regulations, the court-of-choice agreement under the Succession Regulation has some distinctive features which include a special precondition for the conclusion of such an agreement.

As follows from Article 5(1) of the Succession Regulation, the possibility to conclude a choice-of-court agreement depends on whether the deceased has chosen the law of the Member State ${ }^{54}$ according to Article 22 of the Succession Regulation. This is why the role of jurisdictional party autonomy is assessed as complementary to the role of party autonomy regarding the applicable law. ${ }^{55}$ However, the party autonomy provided by Article 22(1) is very restricted and allows the choice of only the law whose nationality the deceased possessed at the time of making the choice or at the time of death. Thus, one can conclude that in order to choose the law of the Member State, the deceased should possess the nationality of this State either at the time of making the choice or at the time of death. ${ }^{56}$ At the same time, the wording of Article 22 of the Succession Regulation (which should be read together with Article 20 that sets the universal application of the law determined under this Regulation) does not preclude the deceased from choosing the law of the third state if he or she possesses its nationality at the time of making the choice or at the time of death. However, since Article 5(1) of the Succession Regulation grants the right to choose the jurisdiction of a court or courts of the Member States, the choice of law of the third state as applicable to the succession excludes the possibility of concluding a choice-of-court agreement for the parties concerned under the Succession Regulation. ${ }^{57}$ Neither can the parties concerned conclude a choice-of-court agreement in favour of the courts of the third states in this situation under the rules of the national law of any Member State. ${ }^{58}$

\footnotetext{
54 As follows from Recitals 82 and 83 of the Succession Regulation, the United Kingdom and Ireland, as well as Denmark, are not bound by this Regulation. They are also not subject to its application. Thus, the term 'Member State' under the Succession Regulation does not refer to them.

55 Buonaiuti (n 48) 149.

56 If the deceased who did not possess the nationality of the Member State at the moment of making a choice chose the law of the Member State as a law governing the succession, the choice will be valid provided that he or she has received the nationality of that Member State by the time of death. Paul Lagarde, 'Article 22' in Ulf Bergquist and others (eds), EU Regulation on Succession and Wills Commentary (Verlag Dr Otto Schmidt KG 2015) 128.

57 Brosch (n 30) 132.

58 Haris Pamboukis and AP Sivitanidis, 'Article 5: Choice-of-Court Agreement' in Pamboukis (n 7) 121; Nikolaidis (n 13) 83; Lein (n 24) 115.
} 
This approach is explained by the impossibility to provide the jurisdiction of third-country courts by EU law. ${ }^{59}$ At the same time, it does not allow for synchronisation between the applicable law and jurisdiction, which, according to recitals 23 and 27 of the Succession Regulation, is one of its main goals (in the case of the law and jurisdiction of the Member States). ${ }^{60}$ This situation was considered regrettable since, in the case of the choice of law of a third country as applicable to the succession, the parties concerned cannot conclude a choice-of-court agreement even with derogation effect, which under certain circumstances may lead to a conflict of jurisdictions. ${ }^{61}$

Other authors go further and suggest setting not only the mere admission of the possibility to conclude a choice-of-court agreement but also the provision of common rules of the Succession Regulation, which will allow the courts of the Member States to decline their jurisdiction in favour of the third-country courts if the parties concerned have chosen the law of that country as applicable to succession and the jurisdiction of its courts provided that they have the power to rule on succession as a whole ${ }^{62}$ and to amend the Succession Regulation with rules focused on cases of lis pendens and of related actions pending before a third country, as well as rules concerning the recognition and enforcement in the Member States of decisions rendered by the third-country courts in succession matters. ${ }^{63}$ If the courts of the third state are not allowed to rule on succession as a whole, the courts of the Member State will have the subsidiary jurisdiction provided by Article 10 of the Succession Regulation. ${ }^{64}$

We support the idea of giving the parties concerned the right to conclude a choice-of-court agreement in favour of the court (courts) of a third state if the law of this state was chosen as applicable to the succession. Indeed, in certain cases ${ }^{65}$ this will allow for the avoidance of the

\footnotetext{
59 Buonaiuti (n 48) 156.

60 ibid.

61 Lein (n 47) 115. To give an example of such a conflict, the author mentions the case when jurisdiction can be determined both under Article 87(2) of Switzerland's Federal Code on Private International Law and under the rules of the Succession Regulation. See Lein (n 47) 116.

62 Fabrizio Marongiu Buonaiuti, 'The EU Succession Regulation and Third Country Courts' (2016) 12(3) Journal of Private International Law 545, 553.

63 ibid, 564.

64 ibid 563-564.

65 For instance, if under the law of the third state its courts have jurisdiction to rule on succession matters in the case where the deceased who had his last habitual residence abroad possessed its nationality and chose its law as applicable to the succession or jurisdiction of its courts and if the last habitual residence of that deceased was the Member State whose courts have jurisdiction to rule on succession as a whole under Article 4 of the Succession Regulation.
} 
conflict of jurisdictions. Consequently, the offer to amend the Succession Regulation rules on declining jurisdiction, lis alibi pendence, related actions and the recognition and enforcement of decisions in this regard should also be supported.

Since Article 5 of the Succession Regulation stipulates that the choice of law made under Article 22 of this Regulation may constitute a ground for the conclusion of a choice-of-court agreement, it should be only a choice of law made to the succession as a whole. Thus, the choice of law made by the deceased regarding the admissibility, substantive validity of disposition upon death, ${ }^{66}$ and the binding effects of the agreement as to succession between the parties, including the conditions for its dissolution, ${ }^{67}$ will not allow the parties concerned to conclude a choice-of-court agreement. ${ }^{68}$ However, as was rightly noticed, this 'small choice of law' will lead to a break up between law and forum. Therefore, it would be better to extend the scope of Article 5 to the cases where a deceased person has made a limited choice of law, provided by Articles 24(2) and 25(3) of the Succession Regulation, since it would allow for at least partial synchronisation. ${ }^{69}$

In should be mentioned that the law of the Member State whose nationality the deceased possessed at the time of death can be applicable not only because of the choice made by the deceased, but also on some other grounds: eg as a consequence of the application of renvoi rules ${ }^{70}$ or rules on the application of the law of the State with which the deceased was more closely connected..$^{71}$ However, governing the succession to the law of the Member State whose nationality the deceased possessed on these grounds will not entitle the parties concerned to conclude a choiceof-court agreement, since Article 5 requires the choice of law made by the deceased as a precondition for the conclusion of a choice-of-court agreement. ${ }^{72}$

Under Article 22(2) of the Succession Regulation, the choice of law "shall be made expressly in a declaration in the form of a disposition of property upon death or shall be demonstrated by the terms of such a disposition'. As to the second type of choice, it is considered that it should

\footnotetext{
66 Succession Regulation, Arts 24(2), 25(3).

67 Succession Regulation, Art 25(3).

68 Buonaiuti (n 48) 154.

69 Marlene Brosch, Rechtswahl und Gerichtsstandsvereinbarung im internationalrn Familien- und Erbrecht der EU (Mohr Siebeck, Tuebingen 2019) 133.

70 Succession Regulation, Art 34(1)(a).

71 Succession Regulation, Art 21(2).

72 Felix Odersky, 'Article 5' in Ulf Bergquist and others (n 56) 72.
} 
follow from the terms of disposition of property upon death. ${ }^{73}$ Regarding the explicit choice of law, opinions vary. Under one point of view, the requirement of Article 22(2) of the Succession Regulation means that the choice of law should be made in a disposition of property upon death. ${ }^{74}$ The second approach is that there is no need to include a choice of law to the disposition upon death; rather, it should meet the formal requirements of such a disposition. ${ }^{75}$

In our opinion, since Article 22(2) of the Succession Regulation does not require that an express choice of law be included in the disposition upon death, such a choice can be made in the disposition upon death or in a separate document. However, in any case, this choice should meet the formal requirements of the disposition upon death and concern 'succession as a whole', as Article 22(1) of the Succession Regulation requires.

If the testator has revoked his or her choice of law or modified it to the law of the third state under Article 22 of the Succession Regulation, the parties will not be able to conclude a choice-of-court agreement, since the requirements of Article 5 will not be met. The choice-of-court agreement concluded by the parties despite the revocation of the choice of law or its modification to the law of the third state is invalid. ${ }^{76}$

In our opinion, the parties concerned by the succession should have the possibility to conclude a choice-of-court agreement not only in situations where the deceased has chosen the law applicable to succession, but also in cases where the application of the conflict of laws rules of the Succession Regulation lead to the application of the law of the Member State whose nationality the deceased possessed. This will contribute to synchronisation between law and jurisdiction, and thus will create an additional mechanism to achieve one of the aims of the Succession Regulation provided by its Recital 27.

\subsection{The content of the choice-of-court agreement and its effects}

As follows from the wording of Article 5(1) of the Succession Regulation, the content of a choice-of-court agreement covers: the circle of

\footnotetext{
73 Lagarde (n 56) 129; Dimitrios Stamatiadis, 'Article 22: Choice of Law' in Pamboukis (n 7) 230; Esperanza Castellanos Ruiz, 'Article 22: Choice of Law' in Calvo Caravaca, Davi and Mansel (n 8) 344. Recital 39 of the Succession Regulation gives the following examples of such situations: 'the deceased had referred in his disposition to specific provisions of the law of the State of his nationality or where he had otherwise mentioned that law'.

74 Lagarde (n 56) 129; Stamatiadis (n 73) 230.

75 Castellanos Ruiz (n 73) 345.

76 Lein (n 47) 118.
} 
issues to be solved by the chosen court; the type of jurisdiction of the chosen court; the chosen court or courts of the Member State.

The circle of issues regarding which the parties can conclude a choice-of-court agreement covers 'any succession matter' in the English version of the Succession Regulation. In comparison, the general jurisdiction rule of Article 4, applicable in the absence of a choice-of-court agreement, provides the jurisdiction to rule on 'succession as a whole'. Versions in most other languages have the same meaning: in Croatian 'o svim nasljednim stvarima' and 'o naslje ivanju u cijelosti'; in French 'sur toute succession' and 'l'ensemble d'une succession', respectively. Thus, the parties concerned may specify that the chosen court will rule on any issue of 'succession' in the meaning of Article 3(1)(a) (which determines the notion of 'succession'), Article 23(2) of the Succession Regulation (which specifies the circle of issues covered by 'succession as a whole') taking into account all the exclusions of its scope provided by Article 1(2) of the Succession Regulation. The wording of Recital 28 of the Succession Regulation allows us to conclude that the parties concerned can conclude a choice-of-court agreement which covers all issues connected with succession or a particular issue if the decision made by a chosen court on that issue does not affect the rights of the other parties to the succession. ${ }^{77}$ If the parties concerned have not specified the issues covered by the choice-of-court agreement, the agreement is considered one that includes all judicial procedures. ${ }^{78}$ However, in our opinion, this conclusion should not be made automatically and it would be appropriate to determine the parties' intent in each case.

The German version of Article 5 of the Succession Regulation uses the term 'Erbsachen' to stipulate the circle of issues which may be submitted to the chosen court (courts), which, unlike the term in other language versions, cannot be determined by reference to Article 3(1)(a) of the Succession Regulation, since the German version of this provision uses the term 'Rechtsnachfolge von Todes wegen', which does not coincide with the term employed in Article 5 of the Succession Regulation. Nevertheless, commentators explain that the meaning of this term should not differ from the meaning of the similar term in other languages, since its interpretation should be made autonomously, taking into consideration the versions in other languages and the provisions of Articles 1 and 23 of the Succession Regulation. ${ }^{79}$

\footnotetext{
77 Eva Lein, 'Artikel 4 EuErb VO' in Anatol Dutta, Johannes Weber (eds), Internationales Erbrecht: EuErbVO, Erbrechtliche Staatsverträge, EGBGB, IntErbRVG, IntErbStR, IntSchenkungsR (CH Beck 2016) 106.

78 Pamboukis and Sivitanidis (n 58) 125.

79 Lein (n 77) 106.
} 
Article 5(1) of the Succession Regulation provides that the jurisdiction which is granted to the court (courts) of a particular Member State under the choice-of-court agreement is an exclusive one, which means that only the chosen court or courts have the jurisdiction to consider the case submitted to the court under the agreement. ${ }^{80}$ The jurisdiction of the chosen court (courts) arises on the basis of Articles 5 and 7(a) of the Succession Regulation..$^{81}$ On the other hand, the effective choice-of-court agreement deprives the courts whose jurisdiction could be determined under the other rules of jurisdiction (Articles 4 and 10 of the Succession Regulation) from ruling on issues covered by the choice-of-court agreement. ${ }^{82}$ In this situation, the court seized under Articles 4 or 10 of the Succession Regulation should decline its jurisdiction according to Article 6(b) of the Succession Regulation. This is why it is recognised that the choice-of-court agreement under the Succession Regulation has prorogation (for the chosen court or courts) and derogation (for the courts which might have jurisdiction under Articles 4 or 10 of the Succession Regulation) effects. ${ }^{83}$

Since the general jurisdiction of the Succession Regulation which covers both contentious and non-contentious proceedings ${ }^{84}$ is conferred on a chosen court, ${ }^{85}$ its prorogated jurisdiction also encompasses both types of proceedings, including the competence to issue a European Certificate of Succession. ${ }^{86}$

As follows from Article 5 of the Succession Regulation, the parties concerned may choose a particular court or courts of a Member State whose nationality the deceased possessed either at the moment of choice of law applicable to the succession or at the moment of death. In the first case, the choice-of-court agreement determines international and internal jurisdiction. In the second case, the internal law of a particu-

\footnotetext{
80 Pamboukis and Sivitanidis (n 58) 125. However, there are some declarations of the parties concerned which can be considered by a court other than a chosen court. They include declarations of acceptance or waiver of succession, of a legacy, or of a reserved share, which under Article 13 of the Succession Regulation can be considered by the court of the Member State of the habitual residence of any person who is entitled to make the respective declaration 'in addition to the court having jurisdiction'. Lein (n 47) 118.

81 Pamboukis and Sivitanidis (n 58) 124.

82 Lein (n 47) 119.

83 Pamboukis and Sivitanidis (n 58) 124; Lein (n 47) 119.

84 This conclusion is made from Article 3(2) and Recital 20 of the Succession Regulation. See Alfonso-Luis Calvo Caravaca, 'Article 4: General Jurisdiction' in Calvo Caravaca, Davì and Mansel (n 8) 134; Felix Odersky, 'Article 4' in Ulf Bergquist and others (n 56) 65. CJEU has made this conclusion from Recital 59 of Succession Regulation. See Case C-20/17 Oberle ECLI:EU:C:2018:485 para 43.

85 Succession Regulation, Art 6 (b).

86 See, Succession Regulation, Art 64.
} 
lar Member State specifies the court which has subject matter and territorial jurisdiction. ${ }^{87}$ The possibility to choose a specific court of the Member State may create conflict between subsequent choice-of-court agreements. In this case, the latter agreement should prevail over the earlier one. ${ }^{88}$

\subsection{Parties to the choice-of-court agreement}

Article 5(1) of the Succession Regulation admits the conclusion of a choice-of-court agreement between 'the parties concerned'. This term is not explained in the Succession Regulation. Therefore, it needs interpretation, which should be done autonomously. ${ }^{89}$ Since the choice-ofcourt agreement can deal with only certain issues and consequently can concern only some persons, it should be determined on a case-by-case basis. ${ }^{90}$ Most authors agree that the circle of parties concerned may include heirs (testate and intestate), legatees and other beneficiaries, specified by a disposition upon death or a disposition inter vivos. ${ }^{91}$ According to one point of view, it encompasses all parties whose rights and duties arise from succession, including creditors. ${ }^{92}$ Such inclusion is explained by the benefits of unity with regard to the regulation of succession, since creditors' claims constitute the liabilities of the inheritance. ${ }^{93}$ Another idea is that the creditors are not sufficiently concerned since they can seize the court that has jurisdiction under Article 4 even if a choice-ofcourt agreement exists. ${ }^{94}$

In our opinion, since 'succession' under Article 3(1)(a) of the Succession Regulation is understood as a '...transfer of assets, rights and obligations by reason of death..., creditors are not the parties concerned by succession, because, despite the fact that their claims can be satisfied in the case of death of their debtor, the reason for this satisfaction is not the death of the deceased, but the contract or other juridical act which created contractual or non-contractual obligations for the deceased. Thus, the creditors are concerned not with the succession but with the performance of contractual or non-contractual obligations under which the deceased was a debtor. This is why we agree that creditors' actions are

\footnotetext{
87 Lein (n 47) 118.

88 Buonaiuti (n 48) 160.

89 Odersky (n 72) 72.

90 Pamboukis and Sivitanidis (n 58) 123-124; Lein (n 47) 116

91 Lein (n 47) 116; Odersky (n 72) 73.

92 Lein (n 47) 116; Pamboukis and Sivitanidis (n 58) 124.

93 Pamboukis and Sivitanidis (n 58) 124.

94 Odersky (n 72) 73.
} 
not succession ones and should be governed by the rules of the private international or procedural law applicable to the respective action (eg the Rome I Regulation or the Brussels I bis Regulation). ${ }^{95}$

It is considered that in contentious proceedings, the circle of parties concerned covers only the claimant (or applicant) and the defendant, since the decisions rendered in these proceedings bind only them. ${ }^{96}$ The determination of the 'parties concerned' in non-contentious proceedings has been seen as more complicated, especially if they are aimed at determining the heirs or beneficiaries or the validity of a will. ${ }^{97}$ Consequently, it may happen that not all the parties concerned are parties to the choice-of-court agreement. In this case, Article 9 of the Succession Regulation should be applied. ${ }^{98}$

In principle, under the Succession Regulation, the deceased cannot choose jurisdiction to succession matters unilaterally. However, some authors admit the choice-of-court agreement, included in an agreement as to succession if it is allowed by the applicable national law. ${ }^{99}$ At the same time, they emphasise that such a choice-of-court agreement should be observed only if all the parties concerned by a particular succession issue, submitted to a chosen court, have expressed their consent with this choice-of-court agreement. ${ }^{100}$ We support the idea that a choice-of-court agreement can be concluded by the parties to the agreement as to succession, especially since Article 9 of the Succession Regulation provides an opportunity for the parties to the proceedings who were not party to the choice-of-court agreement to enter an appearance without contesting the jurisdiction of the chosen court (if they would like this court to continue to exercise jurisdiction) or contest its jurisdiction. In the latter case, the court provided by the choice-of-court agreement should decline its jurisdiction. ${ }^{101}$

\subsection{Form of choice-of-court agreement, the moment of its conclusion and substantive validity}

A choice-of-court agreement should be concluded in written form, contain the signatures of the parties concerned, and the date. Communication by electronic means is deemed equivalent to writing if it provides

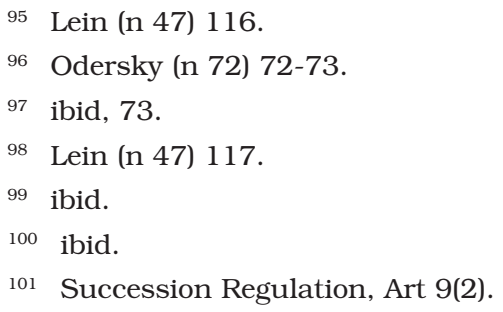


a durable record of the agreement. ${ }^{102}$ Since the provision regarding electronic means sets down nothing as to the signature and date, it was concluded that a choice-of-court agreement concluded by electronic means should contain these elements. ${ }^{103}$ However, there are different points of view as to the mode in which such a signature can be made. According to one view, it is sufficient if the agreement is signed, scanned and transmitted or if it is signed by a qualified electronic signature. ${ }^{104}$ Another view is that in this case the choice-of-court agreement should contain an electronic signature, ${ }^{105}$ a 'digital signature or other technical means of securing the provenance of the communication from the person appearing as a sender. ${ }^{106}$ If one of the parties concerned who is a party to the proceeding does not have such a signature, he or she may expressly accept the jurisdiction of the chosen court according to Article 7(c) of the Succession Regulation. ${ }^{107}$ Actually, Article 5(2) of the Succession Regulation does not require a qualified electronic signature for a choice-ofcourt agreement, but only a durable record of a signed and dated agreement. So, any means which meet these requirements, including sending a signed, scanned and transmitted agreement by email, can be used. However, in the case of the conclusion of a choice-of-court agreement by electronic means, the parties concerned may sign it on different dates. In our opinion, in this situation the agreement is concluded on the date when the party who has signed the agreement most recently has sent it to the other parties concerned. Since the Succession Regulation does not specify that the choice-of-court agreement should constitute one document, we support the idea that it can be concluded by the changing of separate documents, provided that their content is evident. ${ }^{108}$

The Succession Regulation is silent about the moment by which the choice-of-court agreement can be concluded. This is why it is recognised that it can be concluded before the beginning of the succession proceeding, and even before the opening of succession, in other words during the lifetime of the deceased (eg in the succession agreement) provided that it is concluded by all the parties concerned. ${ }^{109}$ However, more often such

\footnotetext{
102 Succession Regulation, Art 5(2).

103 Lein (n 47) 118.

104 Odersky (n 72) 75; Pamboukis and Sivitanidis (n 58) 123.

105 Lein (n 47) 118;

106 Buonaiuti (n 48) 158.

107 Lein (n 47) 118.

108 Odersky (n 72) 75.

109 Lein (n 47) 118; Odersky (n 72) 75. However, under Article 9 of the Succession Regulation, even if the choice-of-court agreement was not concluded by all the parties concerned, the chosen court may still have jurisdiction to rule on the case if the parties concerned enter an appearance without contesting the jurisdiction of the court.
} 
agreements are concluded after the opening of succession, since from this moment the parties concerned know for sure whether the deceased has chosen the law of the Member State as applicable to the succession whose nationality the deceased possessed at the moment of making the choice or at the moment of death. ${ }^{110}$

The substantive validity of the choice-of-court agreement is not governed by the Succession Regulation. We agree that in such circumstances this issue can be solved analogously to the solution of Article 25 of the Brussels I bis Regulation, ${ }^{111,112}$ that is, to determine the substantive validity of the choice-of-court agreement under the law of the Member State whose court (courts) receive jurisdiction according to the choiceof-court agreement. Since the chosen court (courts) can be only courts of the Member State whose law was chosen to govern the succession, the substantive validity of the choice-of-court agreement will be determined under the own law of the court, which governs succession as a whole. ${ }^{113}$

The substantive validity of the choice-of-court agreement should be determined at the moment of making a decision regarding international jurisdiction. ${ }^{114}$ The other possible moments (the time of the conclusion of the choice-of-court agreement and the time the court is seized, which are stipulated, for example, by Article 4 of the Maintenance Regulation ${ }^{115}$ ) are inappropriate for the choice-of-court agreement under the Succession Regulation because the jurisdiction which is granted to the court by this agreement covers contentious and non-contentious proceedings and, as was mentioned above, in the latter type of proceedings one can face a situation where not all the parties were known at the moment of the conclusion of the agreement or even at the moment of seizing a court. ${ }^{116}$

\footnotetext{
110 Buonaiuti (n 48) 152.

111 Regulation (EU) No 1215/2012 of the European Parliament and of the Council of 12 December 2012 on jurisdiction and the recognition and enforcement of judgments in civil and commercial matters (recast) [2012] OJ L351/1.

112 Buonaiuti (n 48) 159; Brosch (n 30) 150. Marlene Brosch also suggests amending Article 5 of the Succession Regulation by a provision which is similar to the rule of Article 25 of the Brussels I bis Regulation. Brosch (n 30) 243, 244.

113 ibid.

114 Brosch (n 30) 151.

115 Council Regulation (EC) No 4/2009 of 18 December 2008 on jurisdiction, applicable law, recognition and enforcement of decisions and cooperation in matters relating to maintenance obligations [2009] OJ L7/1.

116 Brosch (n 30) 151.
} 


\section{Choice-of-court agreements under the Matrimonial Property Regulation}

\subsection{Reasons for the inclusion of the choice-of-court agreement in the Matrimonial Property Regulation}

The destiny of the development of rules on the choice-of-court agreement under the Matrimonial Property Regulation was similar to the drafting of the respective provisions of the Succession Regulation. Despite the fact that the Green Paper adopted by the Commission on the outset of the creation of the Matrimonial Property Regulation provided that it would be advisable to preserve a degree of consistency between the rules on jurisdiction and the conflict rules, and to provide for a choice of court by the spouses', ${ }^{117}$ the Proposal of the Commission of $2011^{118} \mathrm{did}$ not contain any rules regarding choice-of-court agreements. The respective provisions of Article 7 appeared in the Proposal of the Commission of 2016. ${ }^{119}$ According to the Explanatory Memorandum to this Proposal, they were included 'to enhance predictability and the freedom to choose of the spouses'. ${ }^{120}$ For this reason, Article 7 of the Proposal of the Commission of 2016 provided the possibility for the conclusion of a choice-ofcourt agreement for the spouses in favour of the courts of the Member State whose law applies to the matrimonial property regime or the courts of the Member State of the celebration of the marriage. This approach was maintained in the Matrimonial Property Regulation (although with a slight difference: the Matrimonial Property Regulation does not use the term 'celebration of marriage'; instead, it employs the term 'conclusion of marriage'). It is obvious that the possibility to choose the courts of the Member State whose law is applicable to the case was given to provide synchronisation between the jurisdiction and the applicable law, which usually facilitates the proceedings. Both possibilities were granted 'to increase legal certainty, predictability and the autonomy of the parties. ${ }^{121}$

\footnotetext{
117 Commission, 'Green Paper on the conflict of laws in matters concerning matrimonial property regimes, including the question of jurisdiction and mutual recognition' COM (2006) 400 final.

118 Commission, 'Proposal for a Council Regulation on jurisdiction, applicable law and the recognition and enforcement of decisions in matters of matrimonial property regimes' COM (2011) 126 final.

119 Commission, 'Proposal for a Council Regulation on jurisdiction, applicable law and the recognition and enforcement of decisions in matters of matrimonial property regimes' COM (2016) 126 final.

120 Commission, Explanatory Memorandum to Proposal for a Council Regulation on jurisdiction, applicable law and the recognition and enforcement of decisions in matters of matrimonial property regimes 2016, para 5.2.

121 Matrimonial Property Regulation, Recital 36.
} 
In comparison with the parties' autonomy to choose the law applicable to the matrimonial property regime, the autonomy to conclude a choice-of-court agreement under the Matrimonial Property Regulation was defined as 'lower', ${ }^{122}$ since Article 22 of the Matrimonial Property Regulation which governs the choice of applicable law is located at the beginning of the chapter 'Applicable Law' and sets down the primary paths of the determination of the applicable law, while Article 7 of the Matrimonial Property Regulation which stipulates the rules regarding the choice of court is situated after the rules, which provide the primary principles of jurisdiction aimed at avoiding parallel proceedings of contiguous inheritance and family disputes. ${ }^{123}$ Therefore, the choiceof-court agreement under the Matrimonial Property Regulation plays a subsidiary role and can be concluded only in limited cases. ${ }^{124}$

\subsection{Content of a choice-of-court agreement, its parties, form and substantive validity}

As follows from Articles 7, 6, 5, 4, Recital 34 of the Matrimonial Property Regulation, the parties to a choice-of-court agreement may agree to submit a matter of the spouses' matrimonial property regime (except for matters of succession of a spouse; matters of the matrimonial property regime arising in connection with divorce, legal separation or marriage annulment; matters of the matrimonial property regime linked to proceedings pending before the court of a Member State on the succession of a spouse or on divorce, legal separation or marriage annulment) to the courts specified in Article 7 of this Regulation. The term 'matrimonial property regime' should be interpreted autonomously and includes 'any property relationships, between the spouses and in their relations with third parties, resulting directly from the matrimonial relationship, or the dissolution thereof'. ${ }^{125}$ It covers issues of the management and liquidation of matrimonial property, including liquidation as a result of death of one of the spouses. ${ }^{126}$ Article 27 of the Matrimonial Property Regulation which specifies the scope of the law applicable to the matrimonial property regime allows for an approximate list of issues, ${ }^{127}$ considered as matrimonial property issues by this Regulation, to be determined.

\footnotetext{
122 Brosch (n 30) 98.

123 ibid.

124 ibid.

125 Matrimonial Property Regulation, Recital 18.

126 Matrimonial Property Regulation, Recital 18.

127 The list is not exhaustive, since Article 27 of the Matrimonial Property Regulation provides that the 'law applicable to the matrimonial property regime pursuant to this Regulation shall govern, inter alia...' In comparison, the Succession Regulation sets down an
} 
However, it should be noted that not only Article 7 of the Matrimonial Property Regulation provides the rules of choice-of-court agreement, since Article 5(2) of this Regulation sets down that:

jurisdiction in matters of matrimonial property regimes arising in connection with divorce, legal separation or marriage annulment shall be subject to the spouses' agreement where the court that is seised to rule on the application for divorce, legal separation or marriage annulment: (a) is the court of a Member State in which the applicant is habitually resident and the applicant had resided there for at least a year immediately before the application was made, in accordance with the fifth indent of Article 3(1)(a) of Regulation (EC) No 2201/2003; (b) is the court of a Member State of which the applicant is a national and the applicant is habitually resident there and had resided there for at least six months immediately before the application was made, in accordance with sixth indent of Article 3(1)(a) of Regulation (EC) No 2201/2003; (c) is seised pursuant to Article 5 of Regulation (EC) No 2201/2003 in cases of conversion of legal separation into divorce; or (d) is seised pursuant to Article 7 of Regulation (EC) No 2201/2003 in cases of residual jurisdiction.

This means that in order to submit matrimonial property matters arising in connection with divorce, legal separation or marriage annulment to the court which has jurisdiction under the rules, as mentioned in Article 5(2) of the Matrimonial Property Regulation, the parties have to conclude the relevant choice-of-court agreement. ${ }^{128}$ If they have not concluded such an agreement, the court, which is seized under the rules mentioned in Article 5(2) of the Matrimonial Property Regulation, does not have jurisdiction to solve matrimonial property matters arising in connection with divorce, legal separation or marriage annulment. In this case, jurisdiction to solve such matters should be determined under Article 6 of the Matrimonial Property Regulation which specifies jurisdiction in cases 'where no court of a Member State has jurisdiction pursuant to Article 4 or $5 . .$. .

Under Article 7 of the Matrimonial Property Regulation, the spouses can conclude a choice-of-court agreement in favour of the courts provided by this Article, in cases covered by Article 6. Therefore, if the spouses have not chosen one of the courts specified in Article 5(2) of the Matrimonial Property Regulation, which is seized to solve their divorce, legal

exhaustive list of questions which fall within the scope of law applicable to succession, since its Article 23(2) provides that '[t]hat law shall govern in particular...'

${ }_{128}$ This conclusion also follows from Recital 34 of the Matrimonial Property Regulation. See also Lucia Valentová, 'Property Regimes of Spouses and Partners in New EU Regulations: Jurisdiction, Prorogation and Choice of Law' (2016) 16(2) International and Comparative Law Review 221, 230. 
separation or marriage annulment matter, they may conclude a choiceof-court agreement in favour of the courts provided by Article 7 of the Matrimonial Property Regulation to rule on matters of the matrimonial property regime arising in connection with divorce, legal separation or marriage annulment.

Since Article 7 of the Matrimonial Property Regulation allows spouses to submit to the chosen courts 'a matter of the spouses' matrimonial property regime' and does not specify the types of proceeding in which this matter can be considered, it should be concluded that the parties are allowed to submit to the chosen courts matters which are considered either in contentious or non-contentious proceedings (eg a matter on determining the contribution of a spouse to the costs of married life).

Unlike the Succession Regulation, Article 5 of which provides the possibility for the parties concerned to choose 'a court or courts', Article 7(1) of the Matrimonial Property Regulation allows one to choose 'the courts of the Member State'. Therefore, the choice-of-court agreement may set only international jurisdiction. ${ }^{129}$ Consequently, a particular court, which will solve the case, is to be determined under the national rules of the Member State whose courts were chosen under the agreement.

The jurisdiction granted to the courts of a Member State under the choice-of-court agreement provided by Article 7 of the Matrimonial Property Regulation is an exclusive one. In principle, it means that the courts that have jurisdiction to rule on a matrimonial property matter under Article 6 , covered by the choice-of-court agreement, should decline its jurisdiction if a choice-of-court agreement is effective. However, unlike the Succession Regulation, the Matrimonial Property Regulation does not contain a rule as to the court's obligation to decline jurisdiction in this case.

The parties' autonomy is restricted by the condition of Article 7(1) of the Matrimonial Property Regulation to choose 'the courts of the Member State whose law was chosen as applicable pursuant to Article $22,{ }^{130}$ or

\footnotetext{
129 Since this path differs from the solutions offered in other EU Regulations which allow one to choose 'a court or courts' and thus give the parties concerned the possibility to determine not only international, but also national, jurisdiction (see, for example, Article 4(1) of the Maintenance Regulation or Article 5(1) of the Succession Regulation), it was rightly suggested to entitle the parties of the choice-of-court agreement under the Matrimonial Property Regulation to choose national jurisdiction as well. Brosch (n 30) 229, 230.

130 Article 22 of the Matrimonial Property Regulation governs the choice of applicable law. Therefore, it was concluded that if the agreement on the choice of the applicable law is invalid, the choice-of-court agreement in favour of the courts of the Member State whose law was chosen is invalid as well. However, if the chosen law coincides with one of the laws whose application is provided by Article 26(1)(a-b) of the Matrimonial Property Regulation, the choice-of-court agreement is valid, even when the choice-of-law agreement is invalid. Brosch (n 30) 106.
} 
point (a) or (b) of Article 26(1), or the courts of the Member State of the conclusion of the marriage'. This means that besides the courts of the Member State of the conclusion of a marriage, the parties to a choice-ofcourt agreement may choose the courts of the Member State where the spouses or future spouses, or one of them, is habitually resident at the time when the choice-of-law agreement is concluded; or the courts of the Member State of nationality of either spouse or future spouse at the time the choice-of-law agreement is concluded; or the courts of the Member State of the spouses' first common habitual residence after the conclusion of the marriage; or the courts of the Member State of the spouses' common nationality at the time of the conclusion of the marriage; or the courts of the Member State with which the spouses jointly have the closest connection at the time of the conclusion of the marriage, taking into account all the circumstances.

Therefore, the parties to a choice-of-court agreement under the Matrimonial Property Regulation have more options regarding the choice of the courts of the Member States in comparison with the parties to a choiceof-court agreement under the Succession Regulation. ${ }^{131}$ Besides, unlike the Succession Regulation, the Matrimonial Property Regulation does not make the choice of courts of a Member State dependent exclusively on the choice of the law of this State as applicable. It means that the parties who have chosen the law of the Member State applicable to the matrimonial property regime can choose not only the courts of this State, but also the courts of the Member State where the marriage was concluded. The same applies to situations where the choice of the applicable law is absent and when the law is determined under Article 26 of the Matrimonial Property Regulation. In such cases, the parties also have the possibility to choose not only the courts of the Member State whose law is applicable pursuant to Article 26(1)(a) or Article 26(1)(b) of the Matrimonial Property Regulation, but also the courts of the Member State where the marriage was concluded. This is why, although Article 7 of the Matrimonial Property Regulation was primarily aimed at achieving synchronisation between law and forum, this will be impossible if the parties choose the courts of the Member State where the marriage was concluded. ${ }^{132}$

The parties to a choice-of-court agreement provided by Article 7 of the Matrimonial Property Regulation are spouses, thus their identification is easier than the identification of the parties concerned under the Succession Regulation. ${ }^{133}$

\footnotetext{
131 Richard Frimston, 'Article 7: Choice of Court' in Ulf Bergquist and others (n 13) 61-62.

132 Brosch (30) 107.

133 Grieco (n 31) 466.
} 
The formal requirements of a choice-of-court agreement under Article 7(2) of the Matrimonial Property Regulation are the same as under the choice-of-court agreement provided by Article 5 of the Succession Regulation. The Matrimonial Property Regulation does not specify the moment when a choice-of-court agreement can be concluded. Therefore, it is considered that it can be concluded before the commencement of possible proceedings or even afterwards if the proceedings have been dismissed. 134

The substantive validity of the choice-of-court agreement is not governed by the Matrimonial Property Regulation. It was proposed to use the path of Article 25 of the Brussels I bis Regulation ${ }^{135}$ (according to which the substantive validity of the prorogation agreement is governed by the law of the State whose court or courts was or were chosen to settle a dispute) by analogy to fill this gap, ${ }^{136}$ since in many cases the conclusion of a choice-of-court agreement under Article 7 of the Matrimonial Property Regulation would lead to synchronisation between law and forum. In such circumstances, governing the substantive validity of the choice-of-court agreement by the law of the forum would mean its governing by the law applicable to the matrimonial property regime. ${ }^{137}$ In a situation where the parties have concluded a choice-of-law agreement, this would also mean that both agreements are governed by the same law, since under Article 24 the validity of a choice- of-law agreement is determined according to the applicable law. ${ }^{138}$

The Matrimonial Property Regulation does not determine the moment in time which should be taken into account for making a decision as to the validity of a choice-of-court agreement. In principal, two moments can be decisive in this case: the time when the choice-of-court agreement is concluded or the time when the court is seized. ${ }^{139}$ The determination of this moment is especially important in cases where the choice-of-court agreement gives jurisdiction to the courts of the State whose law was chosen as applicable to the matrimonial property regime. Such a choice can be changed under Article 22 of the Matrimonial Property Regulation. We agree that the application of the choice-of-court

\footnotetext{
134 ibid.

135 Regulation (EU) No 1215/2012 of the European Parliament and of the Council of 12 December 2012 on jurisdiction and the recognition and enforcement of judgments in civil and commercial matters (recast) [2012] OJ L351/1.

136 Brosch (n 30) 116-117. The author also suggests including in Article 7 of the Matrimonial Property Regulation a provision which is similar to the rule of Article 25 of the Brussels I bis Regulation. ibid 243, 244.

137 ibid 116-117.

138 ibid 117.

139 ibid.
} 
agreement based on the previous choice-of-law agreement in this situation would lead to non-synchronisation between law and forum. ${ }^{140}$ For this reason, we support the idea that the validity of a choice-of-court agreement under the Matrimonial Property Regulation as well as the validity of the choice-of-law agreement should be determined at the moment the court is seized. ${ }^{141}$

\section{Is it possible to include a choice-of-court agreement in a marriage contract that would grant jurisdiction to rule on both matrimonial property and succession issues?}

As shown above, the rules of the Succession Regulation and the Matrimonial Property Regulation regarding choice-of-court agreements are not identical. Therefore, in order for a choice-of-court agreement, included in a marriage contract, which covers matrimonial property and succession issues, to be valid for both types of proceedings, it should meet the requirements of both instruments.

In our opinion, this is possible only under the following circumstances. Firstly, the dispositions upon the death of a spouse, included in a marriage contract, have to possess all the features of an 'agreement as to succession' provided by Article 3(1)(b) of the Succession Regulation. Secondly, the marriage contract should include a choice-of-law agreement in favour of the law of the Member State whose nationality a spouse possessed when the choice-of-law agreement was concluded (which is admissible according to Article 22(1)(b) of the Matrimonial Property Regulation and Article 22(1) of the Succession Regulation). Thirdly, it should be the law of the Member State whose nationality a deceased spouse (not a surviving one) possessed (it is necessary for the fulfilment of the precondition of the conclusion of a choice-of-court agreement under Article 5 of the Succession Regulation). Fourthly, the choice of law agreement should cover the succession of a deceased spouse 'as a whole' (to meet the requirements of Article 5(1) of the Succession Regulation. Fifthly, the choice-of-court agreement should give jurisdiction to the courts of the Member State whose nationality a deceased spouse possessed at the time of the conclusion of the choice-oflaw agreement (which is admissible under Article 7(1) of the Matrimonial Property Regulation and Article 5(1) of the Succession Regulation). Fifthly, since the Matrimonial Property Regulation allows the parties to choose only international jurisdiction, it is important that such a choice-of-court agreement should provide the jurisdiction of 'the courts' not 'a court' to meet the requirements of both Regulations.

\footnotetext{
140 ibid.

141 ibid 117-118.
} 
The other parties to the succession proceeding, besides the surviving spouse, who were not party to the choice-of-court agreement, may enter an appearance of the chosen court without contesting its jurisdiction, or they may contest the jurisdiction of the chosen court. ${ }^{142}$ In the latter case, the court provided by the choice-of-court agreement should decline its jurisdiction ${ }^{143}$ and should determine the jurisdiction under the rules of the Succession Regulation applicable in the absence of a choice-of-court agreement.

\section{Conclusions}

The provisions of a marriage contract which determine the fate of the estate after the death of one of the spouses are the succession law provisions, and therefore jurisdiction to rule on the relationships arising out of them (including the requirements of a choice-of-court agreement) should be determined under the Succession Regulation. This suggestion is also confirmed by Recital 12 of the Succession Regulation which excludes marriage settlements 'to the extent that such settlements do not deal with succession matters'. Since the Succession Regulation uses the wording 'to the extent', the succession matters of marriage settlements are covered by the Succession Regulation, and the choice-of-court agreement concerning such matters should correspond to the requirements of the Succession Regulation. A court of a Member State seized in succession matters under such a choice-of-court agreement will have jurisdiction to rule on matters of the matrimonial property regime arising in connection with that succession case according to Article 4 of the Matrimonial Property Regulation.

The contractual provisions which govern the division of assets between spouses during the marriage or the terms of liquidation of the matrimonial property regime in cases other than the death of a spouse are matrimonial property law provisions. Therefore, the jurisdiction to rule on relationships arising out of such provisions is determined by the Matrimonial Property Regulation. If a matrimonial property issue which is governed by a marriage contract is not connected with a succession case, for which a court of a Member State is seized under the Succession Regulation, the choice-of-court agreement regarding this issue should correspond to the requirements of the Matrimonial Property Regulation.

\footnotetext{
142 Succession Regulation, Article 9(1).

143 Succession Regulation, Article 9(2).
} 
A choice-of-court agreement included in the marriage contract meets the requirements of both the Succession Regulation and the Matrimonial Property Regulation if: the dispositions upon the death of a spouse, included in the marriage contract, are an 'agreement as to succession' in the sense of Article 3(1)(b) of the Succession Regulation; the marriage contract includes the choice-of-law agreement in favour of the law of the Member State whose nationality a deceased spouse possessed when the choice-of-law agreement was concluded; this choice of law agreement covers the succession of the deceased spouse 'as a whole'; the choice-ofcourt agreement grants jurisdiction to the courts of the Member State whose nationality a deceased spouse possessed at the time of the conclusion of the choice-of-law agreement; it provides the jurisdiction of 'the courts' of a Member State (not 'a court').

\section{(C) $(1) \Theta$}

This work is licensed under the Creative Commons Attribution - Non-Commercial - No Derivatives 4.0 International License.

Suggested citation: I Dikovska, 'Can a Choice-of-Court Agreement Included in a Marriage Contract Meet the Requirements of Both EU Succession and Matrimonial Property Regulations?' (2019) 15 CYELP 269 